\title{
Itinerari di Architettura Moderna a São Paulo, Brasile
}

\author{
Stefano Bertocci \\ Anastasia Cottini
}

Abstract

Questo contributo si presenta come un breve itinerario attraverso quella peculiare modalità con cui l'architettura moderna si manifesta in Brasile, a São Paulo, tra influenze europee, nordamericane e componenti locali che mostrano aspetti quasi vernacolari. Dopo una contestualizzazione del tema, nel quadro dello sviluppo storico della metropoli brasiliana, si affrontano le tematiche legate alla documentazione e alla fruizione del patrimonio moderno paulista. Tale patrimonio può essere documentato, anche in forma speditiva, con metodologie di rilievo digitale integrato, sia allo scopo di consentire la conservazione dell'immagine attuale sia per la fruizione di itinerari nello spazio fisico oppure, da remoto, in quello virtuale. A questo fine, la georeferenziazione dei dati assume un ruolo fondamentale e consente di operare, anche da remoto, con database riferiti a diverse scale, da quella urbana e territoriale a quella di dettaglio dei singoli componenti dei complessi architettonici. II progetto in fase di sviluppo, una volta completate le fasi di censimento e documentazione, consentirà e di gestire e visualizzare nell'insieme le proprietà degli edifici documentati, contribuendo a evidenziare i caratteri patrimoniali di questo patrimonio, oggi spesso a rischio per la rapidità e importanza delle trasformazioni che si sviluppano nella metropoli di São Paulo.

Parole chiave

architettura moderna, São Paulo, itinerari, rilievo digitale integrato, georeferenziazione.

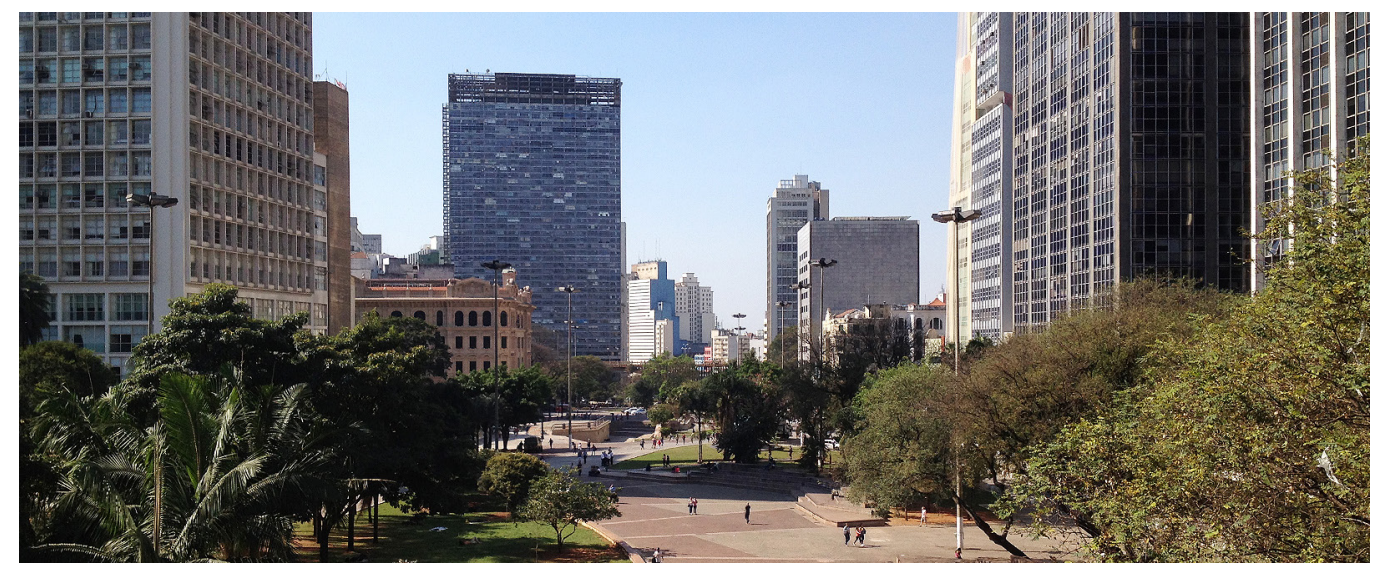




\section{Introduzione}

La comunicazione si inserisce nel quadro delle attività sviluppate sulla base di un accordo di cooperazione internazionale tra il Dipartimento di Architettura (DIDA) di Firenze e la Faculdade de Arquitetura e Urbanismo (USP) di San Paulo, durante le quali sono stati organizzati tre Workshop Internazionali di Rilievo Digitale Integrato a partire dal 20 I7. Dopo un intervento relativo alla presentazione pubblica del nostro progetto di documentazione di una parte di quello che si può chiamare il centro storico della conurbazione di São Paulo, nel 2017, il prof. Lucio Gomes Machado, docente della FAU-USP [I], mi ha proposto una giornata di visita per mostrami gli edifici che maggiormente rappresentano l'interpretazione brasiliana del Movimento Moderno. Ho accettato volentieri e, accompagnato da una mia dottoranda e muniti entrambi di fotocamera, lo abbiamo seguito in un viaggio a dir poco entusiasmante. Ho annotato su di un taccuino i nomi degli architetti, le date e un numero rilevante di artisti che avevano eseguito opere open air a completamento degli ingressi, delle facciate o dei magnifici terrazzi delle coperture. Tutto questo stava conservato nella memoria della mia guida che, con grande dedizione e partecipazione stava narrando anche parte della sua esperienza professionale, avendo visto crescere o addirittura partecipato alla costruzione di alcune di queste opere, con coloriti commenti su autori, colleghi e fatti di cronaca. Successivamente abbiamo elaborato la tematica con studi specifici e una tesi di dottorato. Si presenta ora una trattazione sintetica che mira alla costruzione di esempi di possibili itinerari culturali sul tema dell'architettura moderna di interesse patrimoniale nella città di São Paulo, e che dovrebbe trovare interessanti sviluppi anche per quanto riguarda le opportunità offerte dal mondo della comunicazione digitale del patrimonio.

Fig. I. R. Levi, Teatro Cultura Artistica: mosaico in facciata. Di Cavalcanti, 1950, edificio danneggiato in seguito ad un incendio nel 2008 (foto degli autori, 2017).

Fig. 2. R. Levi. Banco Sulamericano, 1963 l'ultima architettura di (evi (foto degli autc Levi (foto degli autori, 2017)
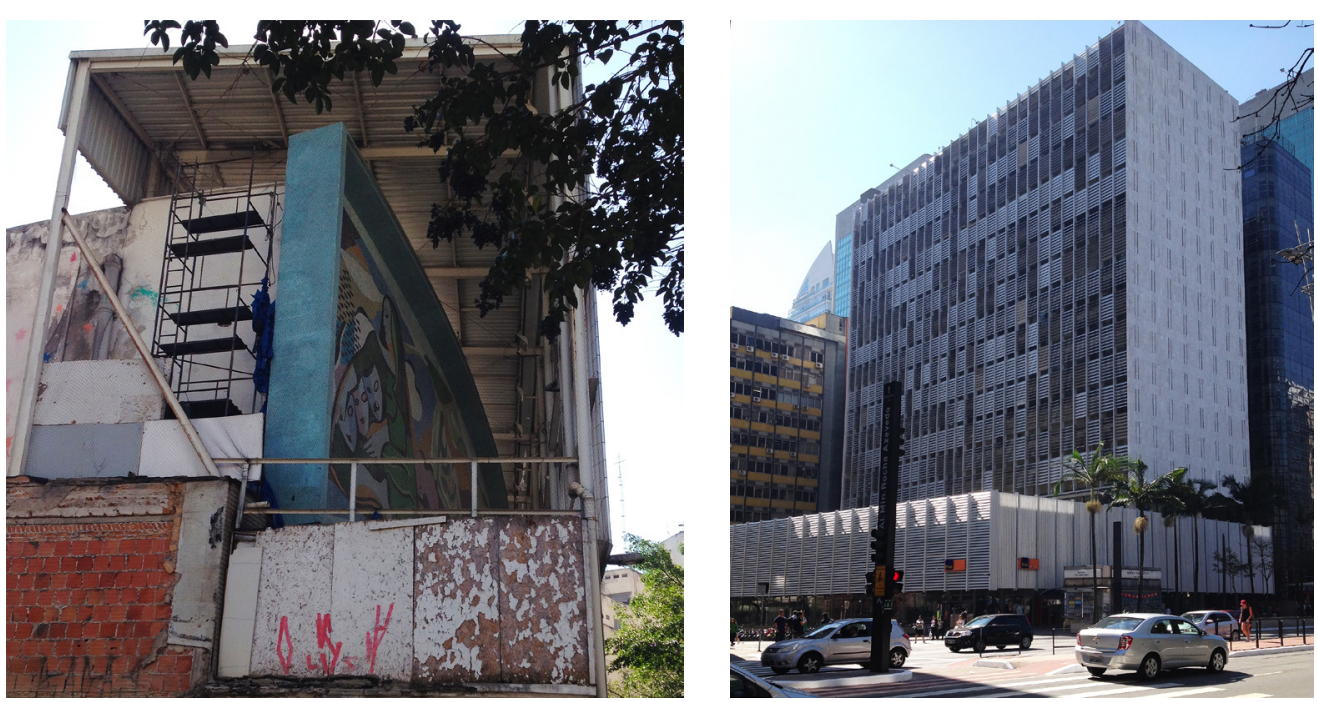

\section{Movimento Moderno in Brasile}

II Movimento Moderno si manifesta in Brasile attraverso l'influenza che Le Corbusier [2] esercita su Costa e sul suo collaboratore Niemeyer, unitamente alla volontà degli architetti locali di adottare nuove e più moderne forme di espressione, mediante l'utilizzo dell'innovativa tecnica del calcestruzzo armato [3]. La nuova architettura brasiliana si richiama alla 'maniera' di Le Corbusier e ai criteri progettuali del Movimento Moderno (utilizzo di volumi puri, di pilotis e di brise-soleil), ma non tralascia gli elementi del genius loci e dell'architettura tradizionale, armonizzando entrambi gli aspetti a favore di una certa espressività.

L'impiego di parametri moderni è inoltre diffuso sia nell'architettura delle classi medie nelle piccole città - è documentata infatti la presenza di case monofamiliari degli anni ' 50 proget- 
tate dagli stessi proprietari con l'ausilio di costruttori esperti, nelle quali è possibile individuare elementi del linguaggio del Movimento Moderno, la conoscenza del quale è trasmessa attraverso il passaparola - sia nella configurazione delle favelas. A causa dell'estensione di tale fenomeno, è possibile parlare di "Modernismo reso Vernacolare" [Lara 2009].

I primi celebri risultati di questo nuovo modo di fare architettura sono gli edifici del Ministero dell'Educazione e della Sanità a Rio de Janeiro (1936-43) di Costa, Niemeyer, Machado Moreira e Reidy e della casa personale di Warchavchik a São Paulo (1927-1928). La dimora dell'architetto ucraino, formatosi alla Scuola Superiore di Architettura di Roma e assistente di Piacentini, è considerata la prima casa modernista di São Paulo, sebbene risponda ai principi lecorbuseriani solo nella composizione della facciata e mantenga una struttura tradizionale in muratura [Vikhreva 20 18]. La modalità con cui l'architetto ha disegnato la casa, senza la volontà di copiare i modelli europei, ma coniugando i volumi puri Moderni con gli elementi decorativi tradizionali e il circostante giardino tropicale, ha lo scopo di ottenere una "dimora propriamente Brasiliana, che si adatta perfettamente al contesto" [4]. Questo modus operandi si relaziona con il contingente manifesto culturale scritto da Oswald De Andrade nel 1928, il Manifesto Antropófago (trad. Manifesto Cannibalista), che esprime il concetto di una cultura, quella Brasiliana, che trova il proprio punto di forza nel 'cannibalizzare' le altre culture, affermandosi contro la dominazione intellettuale europea post-coloniale [Vikhreva 20I8].

Fig. 3. Edifício Itacolomi, 1961, di V. Reif architetto che negli anni ' 30 ha collaborato con Taut nel Bauhaus (foto degli autori, 2017)

Fig. 4. F. Heep, Edificio Lausanne, 1958, (foto degli autori, 2017).
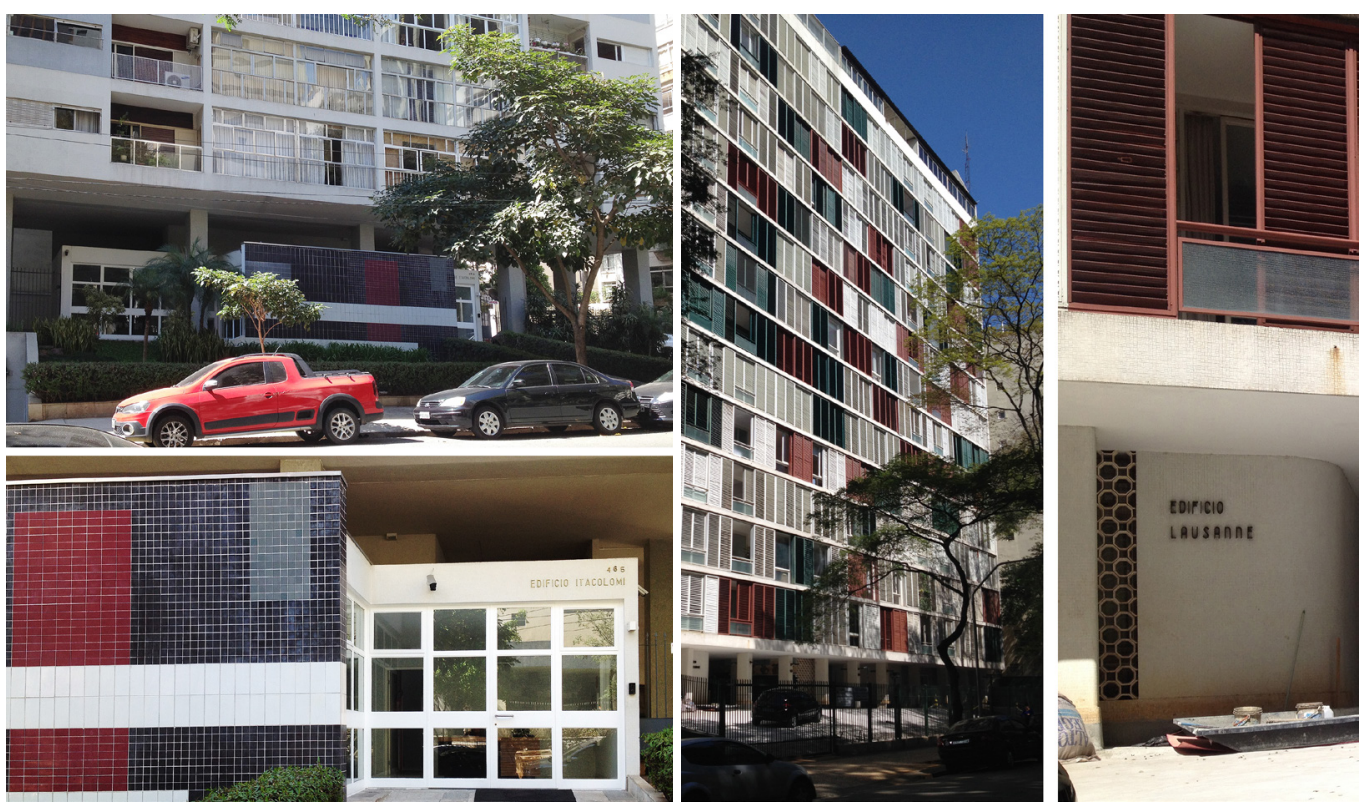

\section{Il caso di São Paulo}

São Paulo, fondata nel 1554 sulla collina detta Triângulo Histórico e caratterizzata da architetture in stile coloniale fino ai primi decenni del ' 900 , assume i connotati di una città 'moderna' in concomitanza con lo sviluppo economico e l'impennata della crescita demografica di fine ' 800 e post-II Guerra Mondiale. La città va incontro a una rapida espansione orizzontale, che gli architetti Ulhôa Cintra e Prestes Maia tentano di controllare tramite il Plano de Avenidas [5] del 1929, per passare a uno sviluppo verticale attorno agli anni '20 e '30, aumentando la densità abitativa e intensificando il processo di demolizione di edifici esistenti e di costruzione di immobili nuovi [Lemos 2016]. I processi di 'crescita selvaggia' hanno modificato l'immagine urbana, accentuandone le discontinuità formali, tanto che São Paulo è definita três cidades em um século [6] [Lima DeToledo 2007] e "o avesso do avesso 
Fig. 5. Siffredi e Bardelli, Edificio Nobel: mosaico in facciata. B. Buffoni, 1950, quest'ultimo ha lavorato per Olivetti sia in Italia che in Brasile (foto degli autori, 2017).

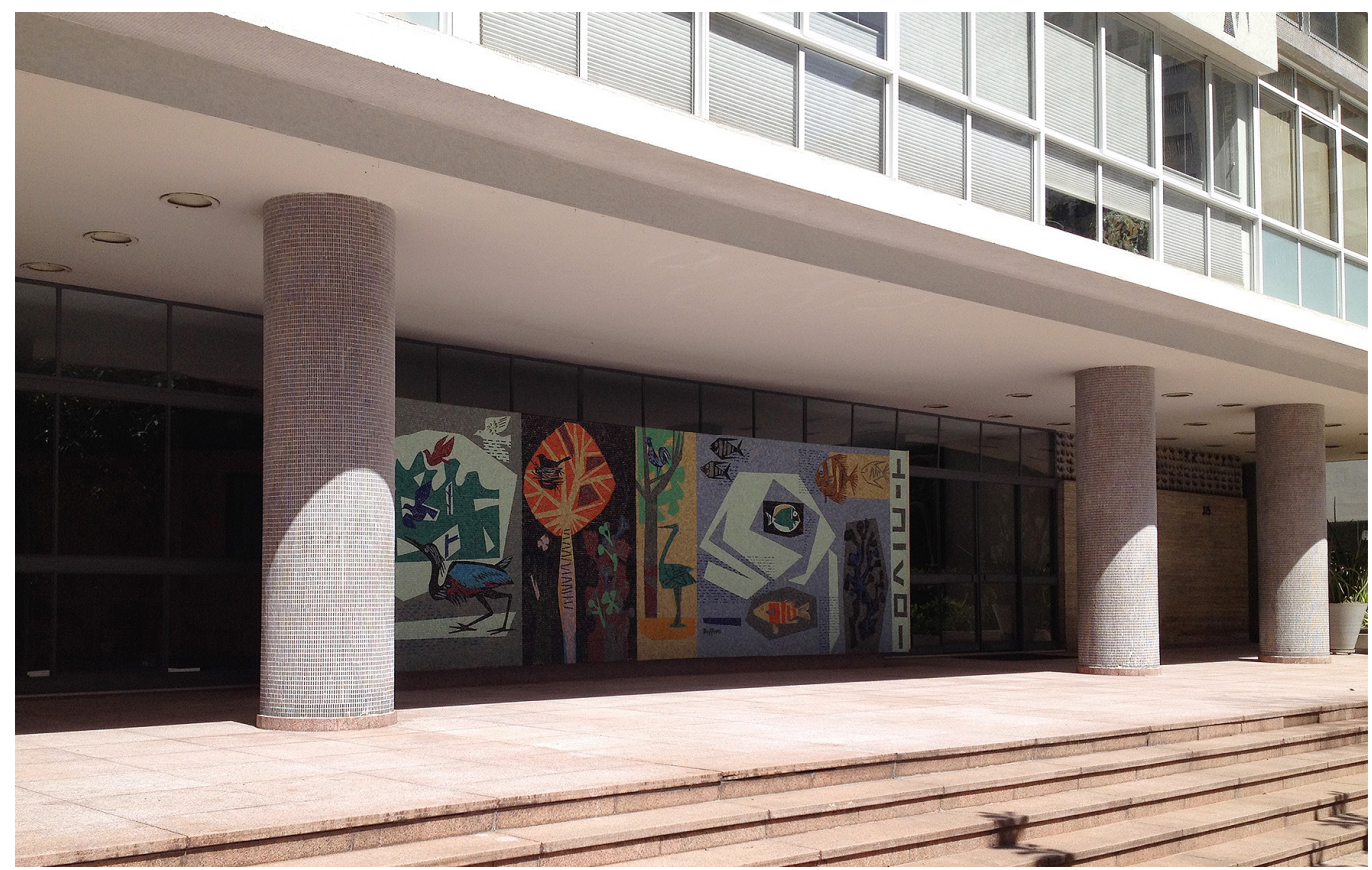

do avesso do avesso" [7]: è una città cosmopolita, con culture contrastanti nel medesimo spazio, nella quale l'impianto urbano originale rimane visibile nonostante la presenza delle moderne avenidas. Ciò rende complessa l'edificazione di nuovi edifici, che devono adattarsi ai lotti esistenti e spesso creano sottosistemi con molteplici funzioni, generando ulteriori spazi urbani e nuovi percorsi. II prodotto che ne consegue è quello di un'immagine urbana con discontinuità formali fortemente accentuate, sia nelle dimensioni degli edifici che nell'eclettismo degli stili utilizzati, con le strutture che creano ulteriori sottoinsiemi di spazi urbani e di nuovi percorsi, anche grazie all'uso di elementi tipici del linguaggio del Movimento Moderno quali le costruzioni sopraelevate su pilotis e le Unité d'habitation [8].
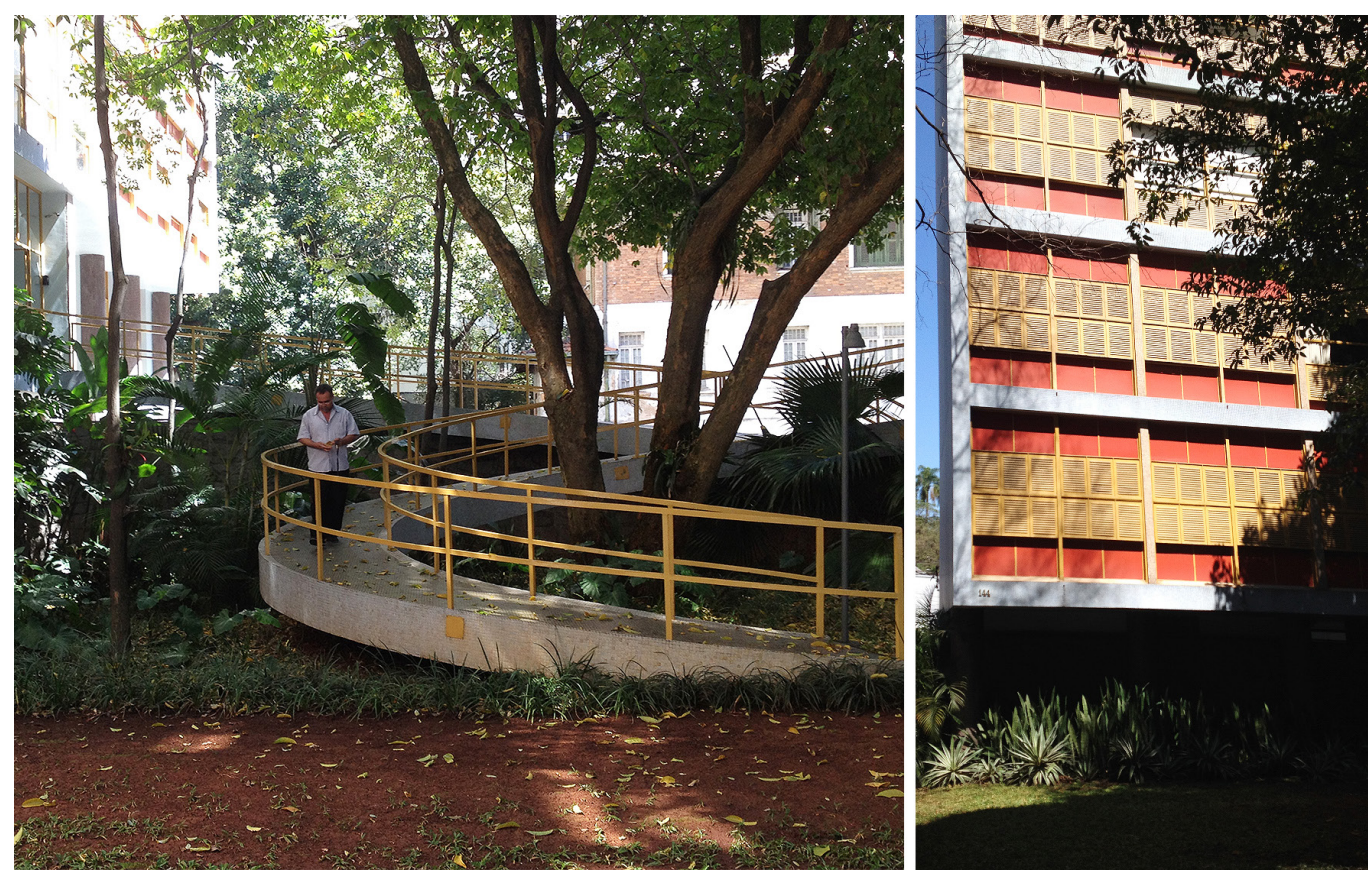
Fig. 7. O. Niemeyer, Edificio Copan, 1961, (foto degli autori, 2017)

Fig. 8. M. Piacentini, Edificio Matarazzo, 1939, (fo degli autori, 2017).
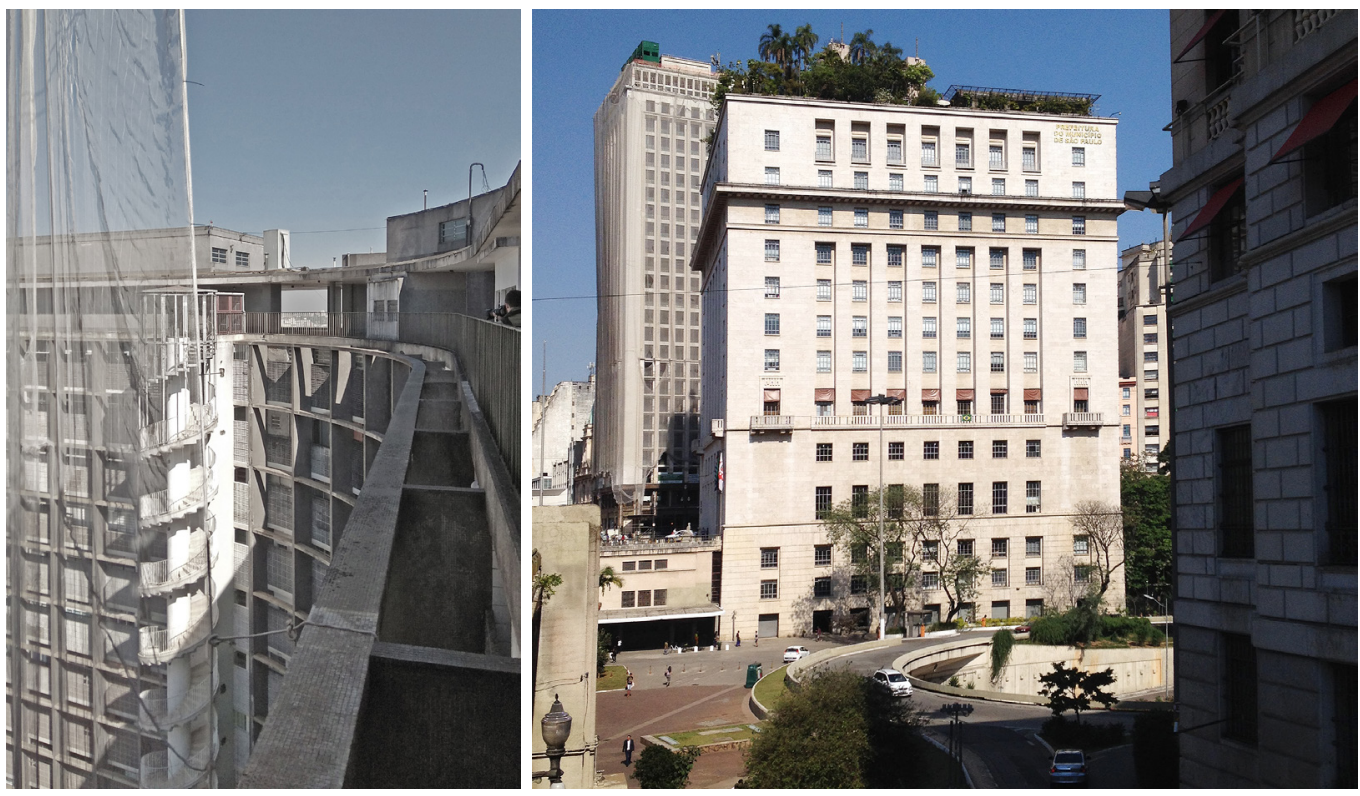

A São Paulo si trovano infatti architetture con citazioni Art Déco, neoclassiche, rinascimentali, o con riferimenti al Movimento Moderno, all'International Style e alla Scuola di Chicago, uniti ecletticamente a manufatti della tradizione coloniale come le decorazioni a mosaico o con azulejos [Cottini 2020]. Questa ricerca di 'modernità' coniugata al vernacolo non si applica soltanto al disegno dell'architettura in senso stretto, ma interessa anche il design degli arredi, delle opere d'arte e del paesaggio circostante, proprio come Warchavchik aveva pionieristicamente fatto durante la progettazione della sua casa, citata nel precedente paragrafo [Anelli 20 I6]. A tal proposito, sono degne di nota le influenze esercitate sull'architettura locale da alcuni architetti, artisti e imprenditori che fanno parte della comunità di Italiani emigrati in Brasile o che discendono da essi, tra i quali si ricordano Marcello Piacentini, Giancarlo Palanti, Pietro Maria Bardi, Lina Bo Bardi, Ermanno Siffredi e Maria Bardelli, Bramante Buffoni, Giuseppe Martinelli, Rino Levi. Questi flussi migratori di intellettuali contribuiscono alla diffusione in Brasile di riviste italiane come Ricordi di architettura (I878-1900), Domus (1928), Casabella (1928), foriere di modelli pratici e teorici che vengono assunti quali paradigmi 'classici' [Cottini 2020].
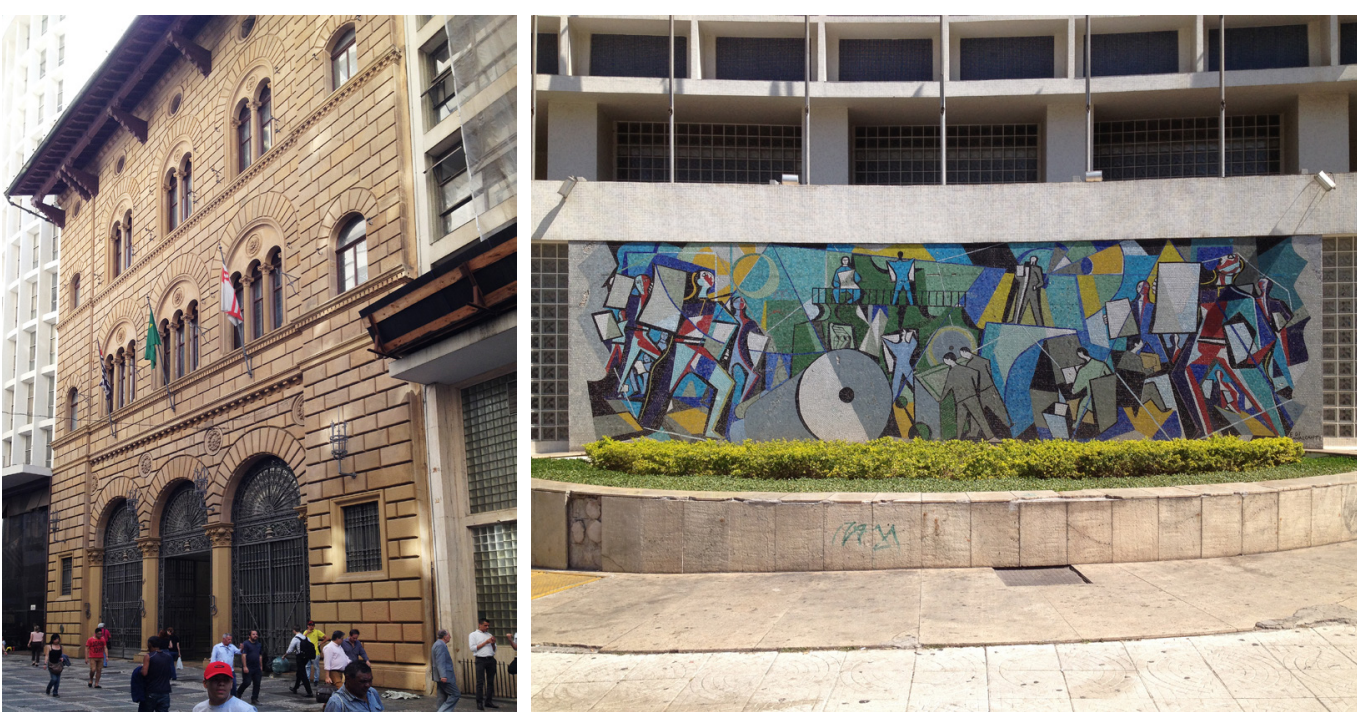


\section{Il progetto di ricerca}

Per salvaguardare il patrimonio storico brasiliano e i valori universali tradizionali, nel 1937 viene fondata l'agenzia IPHAN (Instituto do Patrimônio Histórico e Artístico Nacional) che riconosce e protegge gli edifici con rilevanza storica con il vincolo del tombamento. Negli anni '60, '70 e '80 nascono associazioni su iniziativa congiunta di accademici e cittadini per preservare non solo edifici storici, ma anche tradizioni e paesaggi naturali, suscitando dibattiti sulla definizione di Patrimonio Culturale [Arantes 1993].

A oggi è quindi presente una documentazione sugli edifici moderni di São Paulo, anche iconografica, e una letteratura che analizza il rapporto di questi ultimi con la città, prendendo in considerazione l'impianto urbano tradizionale, il contrasto tra città ideale e città reale, il problema della riqualificazione del centro storico [9].

La ricerca è finalizzata a creare una rete che metta in correlazione le architetture moderne di São Paulo, allo scopo di promuovere la conoscenza di tale patrimonio e renderlo fruibile anche da remoto. Lo scopo è quello di promuovere la conoscenza delle forme in cui il Movimento Moderno si manifesta all'interno della città, grazie all'acquisizione della documentazione con metodologie di rilievo digitale integrato e con documentazione fotografica, finalizzata alla catalogazione e georeferenziazione delle architetture documentate.

Sfruttando le potenzialità delle basi di dati georeferenziati è possibile mettere in correlazione una base cartografica con differenti tipologie di informazioni aggiornabili e integrabili nel tempo, ricavate dallo studio delle fonti storiche e dall'acquisizione dati in situ. Ciò permette di ottenere delle mappe digitali con due reti parallele di percorsi tematici (nello spazio fisico e nello spazio virtuale) che connettono le manifestazioni puntiformi degli edifici moderni alla dimensione della città. A tale scopo si ritiene opportuno utilizzare strumenti open-source [I0] di georeferenziazione del Patrimonio, utili sia perché non hanno costi di utilizzo e possono essere personalizzabili a seconda delle singole esigenze, sia perché mirano a uniformare la metodologia di catalogazione del Patrimonio Culturale attraverso l'adozione di standard per l'inventariazione, per la semantica del modello 3D, per l'interscambio di dati. Tali strumenti permettono a istituzioni e professionisti del settore, previa autenticazione, di inserire dati e documentazione relativi ai casi-studio inventariati, in relazione con le basi car-
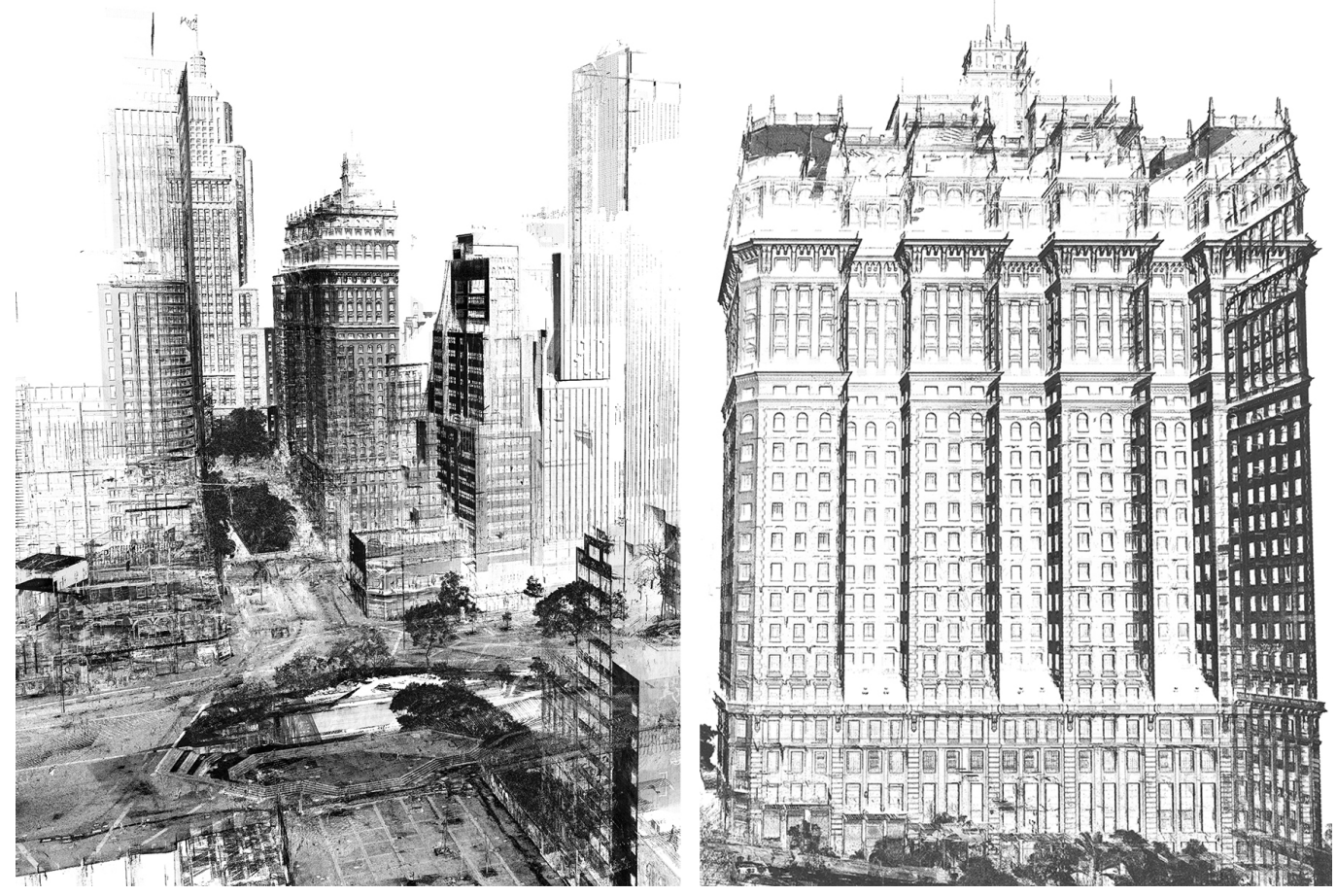
tografiche contemporanee e storiche. I fruitori, che siano studiosi del settore, amministrazioni od utenti occasionali, possono quindi accedere a informazioni selezionate e individuare le relazioni esistenti reciprocamente tra gli elementi segnalati sulla mappa, o tra gli elementi e il territorio, od ancora tra gli elementi e i layer di informazioni di varia natura a essi associati. In questo modo è possibile operare da remoto a più scale di dettaglio, da quella globale e territoriale a quella di dettaglio dei singoli componenti del complesso architettonico.

Un primo esempio di tale lavoro è fornito dalla campagna di rilievo sulla Av. São João, nel centro storico di São Paulo, in occasione di una tesi di laurea discussa nel 20 I, e della quale abbiamo dato conto in alcune pubblicazioni [ I l]: le operazioni di rilievo digitale integrato con laser-scanner e fotogrammetria sono state affiancate da un'attività di schedatura delle facciate dei fronti urbani (figg. I0, I I).

Fig. I I. In alto: esempio di schedatura delle facciate degli edifici dell'Avenida São João. In basso: disegno in CAD e fotopiano di una porzione dell'Avenida (elaborazione grafica A Cottini, C. Alessi).

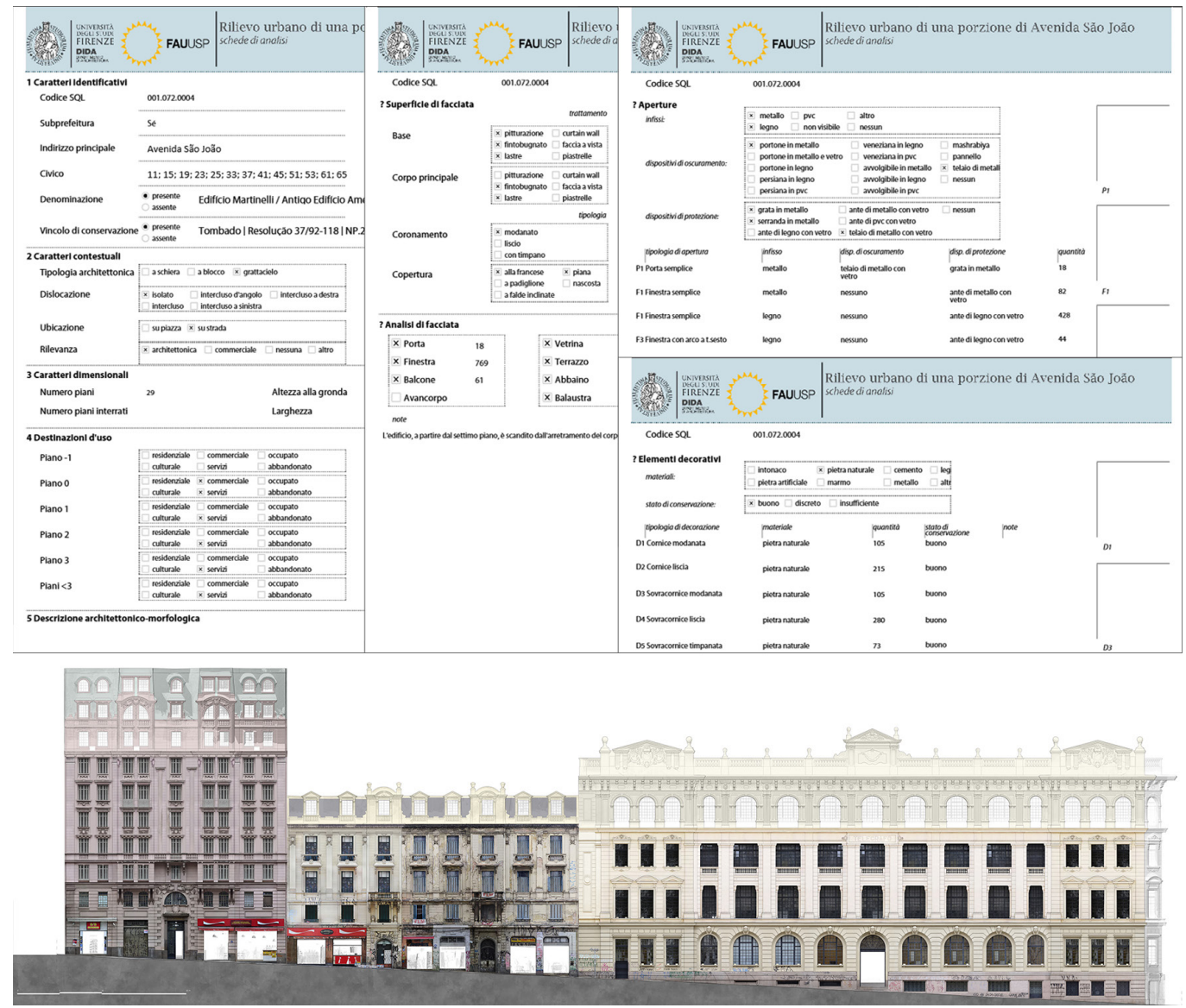

\section{Conclusioni}

II rilievo digitale 3D del Patrimonio Culturale, anche effettuato in forme speditive - laser scanner con mappatura fotografica, fotogrammetria da terra, aerofotogrammetria, è utile per garantire, oltre alla conservazione del dato e della forma del Patrimonio al momento dell'indagine, l'accessibilità da remoto e la diffusione della conoscenza dell'architettura sia nel caso in cui sia impossibile accedervi fisicamente, sia per le persone con disabilità (virtual tour degli edifici con barriere architettoniche, modelli tattili stampati in 3D per i non vedenti). Nel caso specifico, la possibilità di operare con dati riferiti a diverse scale di dettaglio e georeferenziati consente di gestire e visualizzare nell'insieme elementi del Patrimonio territorialmente distanziati e dislocati nella municipalità di São Paulo. In aggiunta, ciò rende possibile 
considerare l'opera nella propria interezza e indagare il modernismo paulista come progetto complessivo di composizione architettonica, design di interni, integrazione con opere d'arte e pianificazione paesaggistica. Un ulteriore aspetto da considerare è, poi, quello del tempo, in quanto le operazioni di rilievo e documentazione fissano lo stato di fatto dell'edificio in un preciso momento e permettono di recuperarne l'immagine in futuro. In una città in costante mutamento come São Paulo occorre tener presente tale fattore e affrontarlo aggiornando i dati dopo un determinato lasso temporale, ad esempio per monitorare lo stato di conservazione o le variazioni di destinazione d'uso dell'edificio.

\section{Note}

[I] II prof. Lucio Gomes Machado, docente della FAU-USP, è stato professore di Storia dell'Architettura e del Design e curatore delle $3^{\mathrm{a}}$ e $4^{\mathrm{a}}$ Bienais Internacionais de Arquitetura.

[2] Nel 1929 Le Corbusier compie un viaggio a São Paulo e a Rio de Janeiro [Muntoni 2009].

[3] Nel 1899 nasce a São Paulo il Centro di Studi sulla Resistenza dei Materiali, dove si studiano la progettazione e costruzione in cemento armato, su brevetto del sistema Hennebique [Anelli R. (20l4). São Paulo: struttura urbana di estensione territoriale. In area, I 14: <https://www.area-arch.it/sao-paulo-urban-structure-of-territorial-extension/> (consultato il 20 maggio 2021 ). Tra il '20 e il '40 la tecnologia del cemento armato si diffonde negli ambienti accademici e negli studi professionali ed è pubblicizzata nelle riviste del settore come simbolo di progresso tecnico e di sviluppo sociale ed economico, fino ad approdare a una vera e propria normazione [Dos Santos R. E. (2008). A armação do concreto no Brasil. História da difusão da tecnologia do concreto armado e da construção de sua hegemonia. Belo Horizonte. Tesi di Dottorato].

[4] Ferraz Geraldo, 1965. Warchavchik e a introdução da nova arquitetura no Brasil: 1925 a 1940. São Paulo: Museu de Arte de São Paulo, 1965.

[5] Piano che struttura la crescita cittadina all'interno di un sistema di vie radiali e perimetrali ad anello.

[6] Trad: "tre città in un secolo".

[7] Trad: "il contrario del contrario del contrario del contrario", verso della canzone Sampa (1978) di Caetano Veloso.

[8] L'esempio più celebre di tale paradigma abitativo a San Paolo è rappresentato dall'Edificio Copan (1952-66) dell'architetto Oscar Niemeyer.

[9] Si vedano ad esempio: Debenedetti E., Salmoni A. (1953). Architettura italiana a San Paolo. Inst. Cult. Italo-Brasileiro; LéviStrauss C. (1996). Saudades de São Paulo. São Paulo: Instituto Moreira Salles; Goodwin, P.L. (1943). Brazil builds: architecture new and old, 1652-1942. New York: The Museum of Modern Art; Segawa, H. (20 10). Arquiteturas no Brasil 1900-1990. São Paulo: EDUSP: <http://centrohistoricosp.mackenzie.br/> (consultato il 22 febbraio $202 \mathrm{I}$ ).

[ I0] Per esempio la piattaforma <https://www.archesproject.org/>, sviluppata da Getty Conservation Institute e World Monuments Fund, "Arches has been purpose-built for the international cultural heritage field, and can be used to inventory and document buildings and other structures, cultural landscapes, heritage ensembles or districts, as well as archaeological sites. As open-source software, Arches is freely available to use and customize, without licensing or upgrade costs, and it is capable of being configured and extended to meet the needs of particular users. Arches incorporates international standards for heritage, information management, and software, leading to better practices in the creation and management of heritage data and facilitating data exchange and longevity in spite of advance $s$ in technology": <https://www.wmf.org/project/arches-project> (consultato il 22 febbraio 202I).

[I I] Si vedano: Cottini A. (20 |9). II disegno dei fronti urbani dell'Avenida São João nel centro storico di São Paulo in Brasile. In P. Belardi (a cura di). Riflessioni: l'arte del disegno/ il disegno dell'arte. Reflections: the art of drawing/ the drawing of art. Atti del $41^{\circ}$ Convegno UID. Perugia, 19-2I Settembre 2019, pp. 58 I-588. Roma: Gangemi Editore; Bertocci S. et al. (2018). Progetti di ricerca per la documentazione del centro storico di Sao Paolo in Brasile in collaborazione con USP. In S. Bertocci Programmi multidisciplinari per l'internazionalizzazione della ricerca. Firenze: didapress; Bertocci S. et al. (2019). LabSAMPA: Rilievo nel centro storico di San Paolo per l'educazione alla tutela del patrimonio. In Bertocci S., Conte A. II Simposio UID di internazionalizzazione della ricerca. Patrimoni culturali, Architettura, Paesaggio e Design tra ricerca e sperimentazione didattica. Firenze: didapress.

\section{Crediti}

Introduzione, II Movimento Moderno in Brasile, II caso di Sao Paulo sono di S. Bertocci

Il progetto di ricerca, Conclusioni sono di A. Cottini

\section{Riferimenti bibliografici}

Anelli R. (2016). Roots of Brazilian Design: Identity and Modern Aesthetics. In SP-ARTE $365<$ https://www.sp-arte.com/en/ editorial/roots-of-brazilian-design-identity-and-modern-aesthetics-by-renato-anelli/> (consultato il 20 maggio 202 I).

Arantes A. (1993). Le pietre miliari del paesaggio urbano: Il caso del Brasile. In La Ricerca Folklorica, Brescia: Grafo Spa, n. 28, pp. $17-28$.

Cottini A. (2020). II contributo degli architetti italiani nella San Paolo modernista. In Firenze Architettura Quaderni 2020. Oriente-Occidente rilievi, XXIV, pp. I02-107. Firenze: Firenze University Press. <https://www.wmf.org/project/arches-project> (consultato il 22 febbraio 2021 ). 
Debenedetti E., Salmoni A. (1953). Architettura italiana a San Paolo. Inst. Cult. Italo-Brasileiro.

Goodwin P.L. (1943). Brazil builds: architecture new and old, I652-1942. New York:The Museum of Modern Art.

Lara F.L. (2009). Modernism Made Vernacular:The Brazilian Case. In Journal of Architectural Education, vol. 63, pp.4I-50.

Lemos C.A.C. (2016). Como nasceram as cidades brasileiras. São Paulo: Studio Nobel.

Lévi-Strauss C. (1996). Saudades de São Paulo. São Paulo: Instituto Moreira Salles.

Lima De Toledo B. (2007). São Paulo: três cidades em um sécul. São Paulo: Cosac Naify.

Muntoni A. (2009). Lineamenti di storia dell'architettura contemporanea. Bari: Editori Laterza.

Segawa H. (2010). Arquiteturas no Brasil 1900-1 990. São Paulo: EDUSP: <http://centrohistoricosp.mackenzie.br/> (consultato il 22 febbraio 2021 )

Vikhreva N. (2018). The roots of Brasilian Modern Architecture. In J. Cunha Pimentel, A. Trevisan, A. Cardoso (a cura di). Regionalism, Nationalism \& Modern Architecture. Proceedings. Porto: ESAP, October 25-27, 20 I 8, pp. 465-473.

\section{Autori}

Stefano Bertocci, Università degli Studi di Firenze, stefano.bertocci@unifi.it

Anastasia Cottini, Università degli Studi di Firenze, anastasia.cottini@unifi.it

Per citare questo capitolo: Bertocci Stefano, Cottini Anastasia (2021). Itinerari di Architettura Moderna a São Paulo, Brasile/Modern architecture itineraries in São Paulo, Brazil. In Arena A., Arena M., Mediati D., Raffa P. (a cura di). Connettere. Un disegno per annodare e tessere. Linguaggi Distanze Tecnologie. Atti del $42^{\circ}$ Convegno Internazionale dei Docenti delle Discipline della Rappresentazione/Connecting. Drawing for weaving relationship. Languages Distances Technologies. Proceedings of the $42^{\text {th }}$ International Conference of Representation Disciplines Teachers. Milano: FrancoAngeli, 1352-1369. 


\title{
Modern Architecture Itineraries in São Paulo, Brazil
}

\author{
Stefano Bertocci \\ Anastasia Cottini
}

Abstract

This contribution is presented as a short itinerary through the peculiar way in which modern architecture manifests itself in Brazil, in São Paulo, between European and North American influences and local components that almost show vernacular aspects. After a contextualization of the theme, within the framework of the historical development of the Brazilian metropolis, the issues related to the documentation and fruition of the Paulist Modern Heritage are addressed.This patrimony can be documented, even in expeditive forms, with integrated digital surveying methodologies, both for the purpose of preserving the current image and for the use of itineraries in the physical space or in the virtual one - remotely. To this end, the geo-referencing of the data takes on a fundamental role and allows to operate, even remotely, with databases related to different scales, from the urban and territorial one to the one of detail of the single components of the architectural complexes. The project under development, once the phases of census and documentation are completed, will allow both to manage and visualize the properties of the documented buildings as a whole, contributing to highlight the patrimonial characteristics of this heritage, often at risk today for the speed and importance of the transformations that develop in the metropolis of São Paulo.

Keywords

modern architecture, São Paulo, routes, integrated digital survey, georeferencing

A portion of the historic center of São Paulo, the

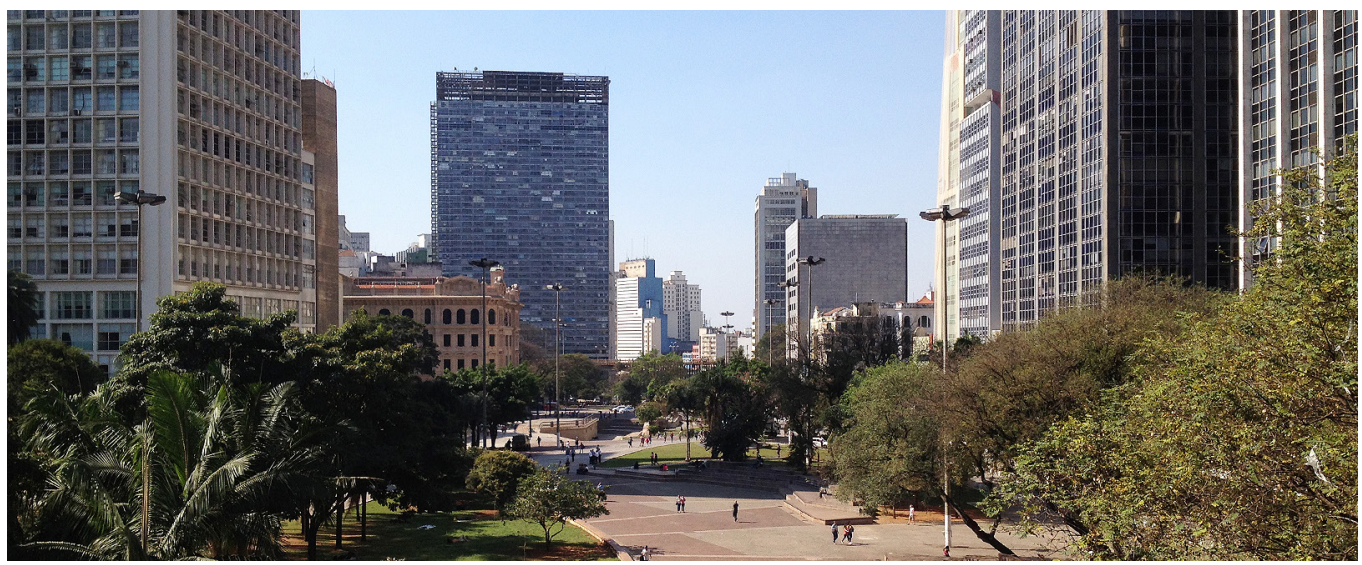




\section{Overview}

The communication is part of the activities developed on the basis of an international cooperation agreement between the Department of Architecture (DIDA) of Florence and the Faculdade de Arquitetura e Urbanismo (USP) in San Paulo, during which three International Integrated Digital Survey Workshops were organized starting in 2017. After a speech related to the public presentation of our project documentation of a part of what can be called the historic center of the conurbation of São Paulo, in 2017, Prof. Lucio Gomes Machado, professor of FAU-USP [I], offered me a visit to show me the buildings that most represent the Brazilian interpretation of the Modern Movement. I accepted willingly and, accompanied by a Phd student and both equipped with a camera, we followed him on a journey that was nothing short of exciting. I noted on a notebook the names of the architects, the dates and a significant number of artists who had performed open air works to complete the entrances, facades or magnificent terraces of the roofs. All this was preserved in the memory of my guide who, with great dedication and participation was also narrating part of his professional experience, having seen grow or even participated in the construction of some of these works, with colorful commentaries on authors, colleagues and news stories. We then developed the topic with specific studies and a doctoral thesis. It is now presented a summary that aims to build examples of possible cultural itineraries on the theme of Modern Architecture of Heritage interest in the city of São Paulo, and which should find interesting developments also with regard to the opportunities offered by the world of digital communication of the Heritage.

Fig. I. R. Levi, Teatro Cultura Artistica: mosaic in façade. Di Cavalcanti (1950): building damaged after a fire in 2008 (photo by the authors).

Fig. 2. R. Levi, Banco Sulamericano, 1963; the last architecture of Levi (photo by the authors)
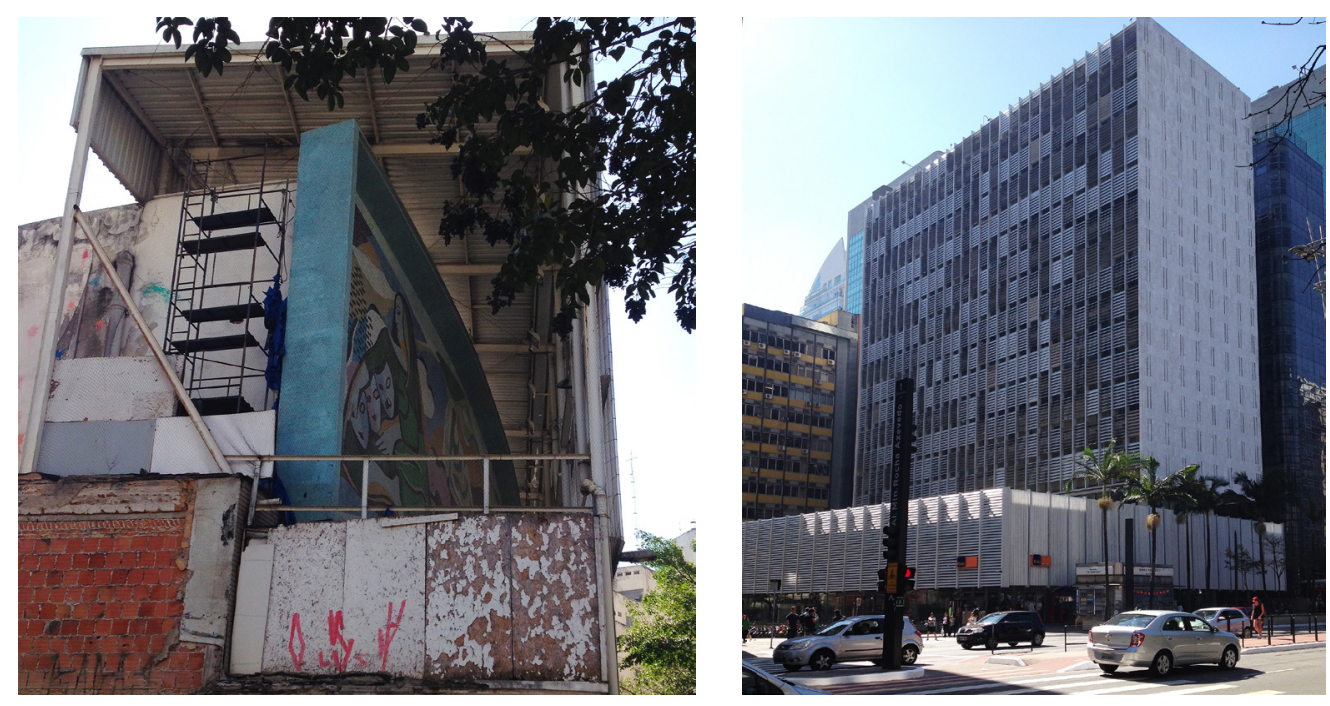

\section{The Modern Movement in Brazil}

The Modern Movement manifests itself in Brazil through the influence that Le Corbusier [2] exerts on Costa and his collaborator Niemeyer, together with the will of local architects to adopt new and more modern forms of expression, using the innovative reinforced concrete technique [3]. The new Brazilian architecture recalls the manner of Le Corbusier and the design criteria of the Modern Movement (use of pure volumes, pilotis and brise-soleil), but does not neglect the elements of genius loci and traditional architecture, harmonizing both aspects in favour of a certain expressiveness.

The use of modern parameters is also widespread both in the architecture of the middle classes in small cities - is documented in fact the presence of single-family homes of the " 50 s 
designed by the same owners with the help of experienced builders, in which it is possible to identify elements of the language of the Modern Movement, the knowledge of which is transmitted through word of mouth - both in the configuration of the favelas. Because of the extent of this phenomenon, it is possible to speak of "Modernism made Vernacular" [Lara 2009].

The first famous results of this new way of doing architecture are the buildings of the Ministry of Education and Health in Rio de Janeiro (1936-43) of Costa, Niemeyer, Machado Moreira and Reidy and the personal home of Warchavchik in São Paulo (1927-1928). The home of the Ukrainian architect, trained at the High School of Architecture in Rome and assistant of Piacentini, is considered the first modernist house of São Paulo, although it corresponds to the Lecorbuserian principles only in the composition of the facade and maintains a traditional masonry structure [Vikhreva 20I8]. The way in which the architect designed the house, without the will to copy the European models, but combining the pure modern volumes with the traditional decorative elements and the surrounding tropical garden, aims to obtain a "properly Brazilian home, which fits perfectly in the context" [4]. This modus operandi relates to the cultural manifesto written by Oswald De Andrade in 1928, the Manifesto Antropófago (trad. Cannibalist Manifesto), which expresses the concept of a culture, the Brazilian one, which finds its strength in the "cannibalisation" of other cultures, asserting itself against the post-colonial European intellectual domination [Vikhreva 20 I8].

Fig. 3. Edifício Itacolomi, 1961, by V. Reif architect who in the 1930s collaborated with Taut in the Bauhaus (photo by the authors)

Fig. 4. F. Heep. Lausanne Building, 1958 (photo by the authors).
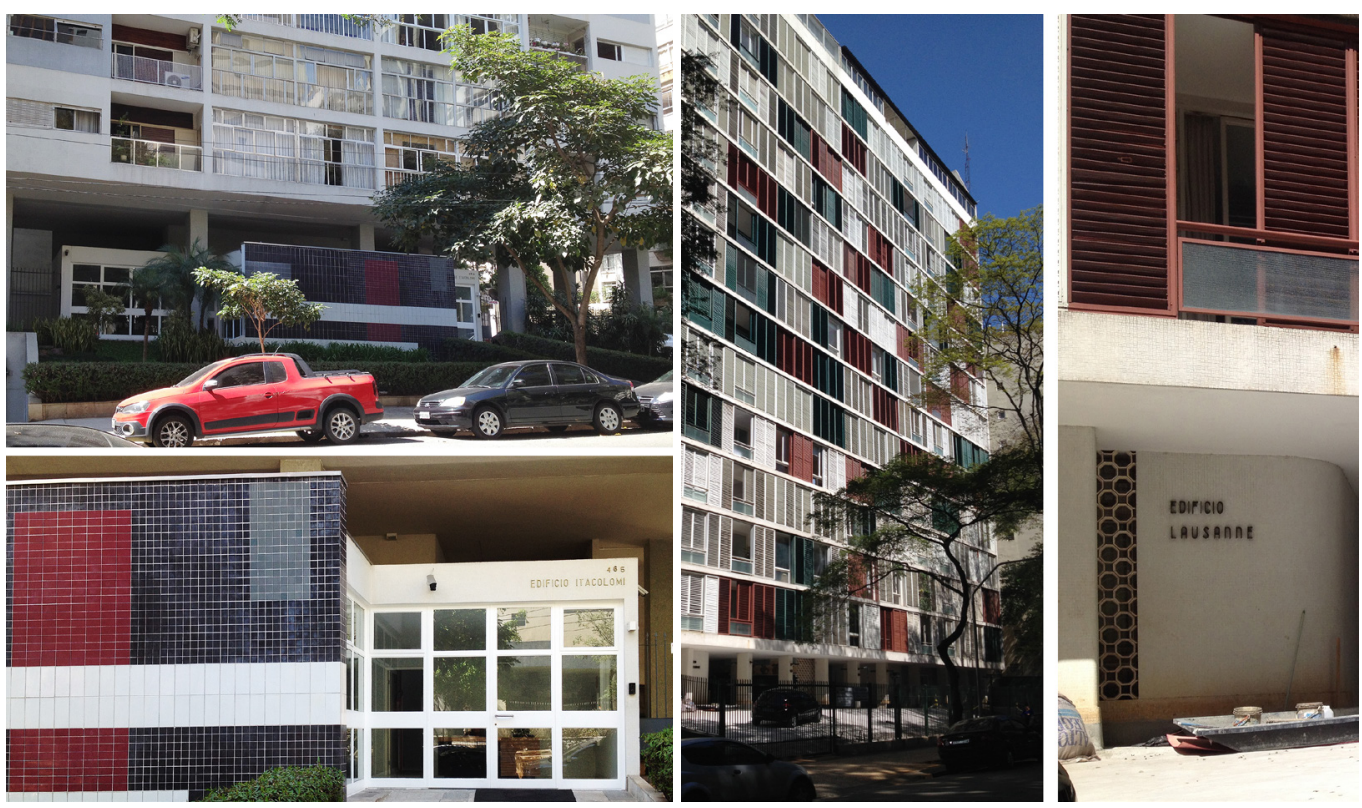

The São Paulo case

São Paulo, founded in I 554 on the hill called Triângulo Histórico and characterized by colonial architecture until the first decades of the 900, takes on the connotations of a 'modern' city in conjunction with economic development and the surge in population growth in the late 19th and post-II World War. The city is undergoing a rapid horizontal expansion, which architects Ulhôa Cintra and Prestes Maia try to control through the Plano de Avenidas [5] of 1929, to move to a vertical development around the 1920s and 1930s, increasing population density and intensifying the process of demolition of existing buildings and construction of new buildings [Lemos 2016]. The processes of 'wild growth' have changed the urban image, accentuating the formal discontinuities, so much that São Paulo is defined "três cidades em um século" [6] [Lima De Toledo 2007] and "o avesso do avesso do avesso do avesso" [7]. 
Fig. 5. Siffredi \& Bardelli, Nobel Building: mosaic in façade. B. Buffoni, 1950, the latter has worked for Olivetti both in Italy and in Brazil (photo by the authors).

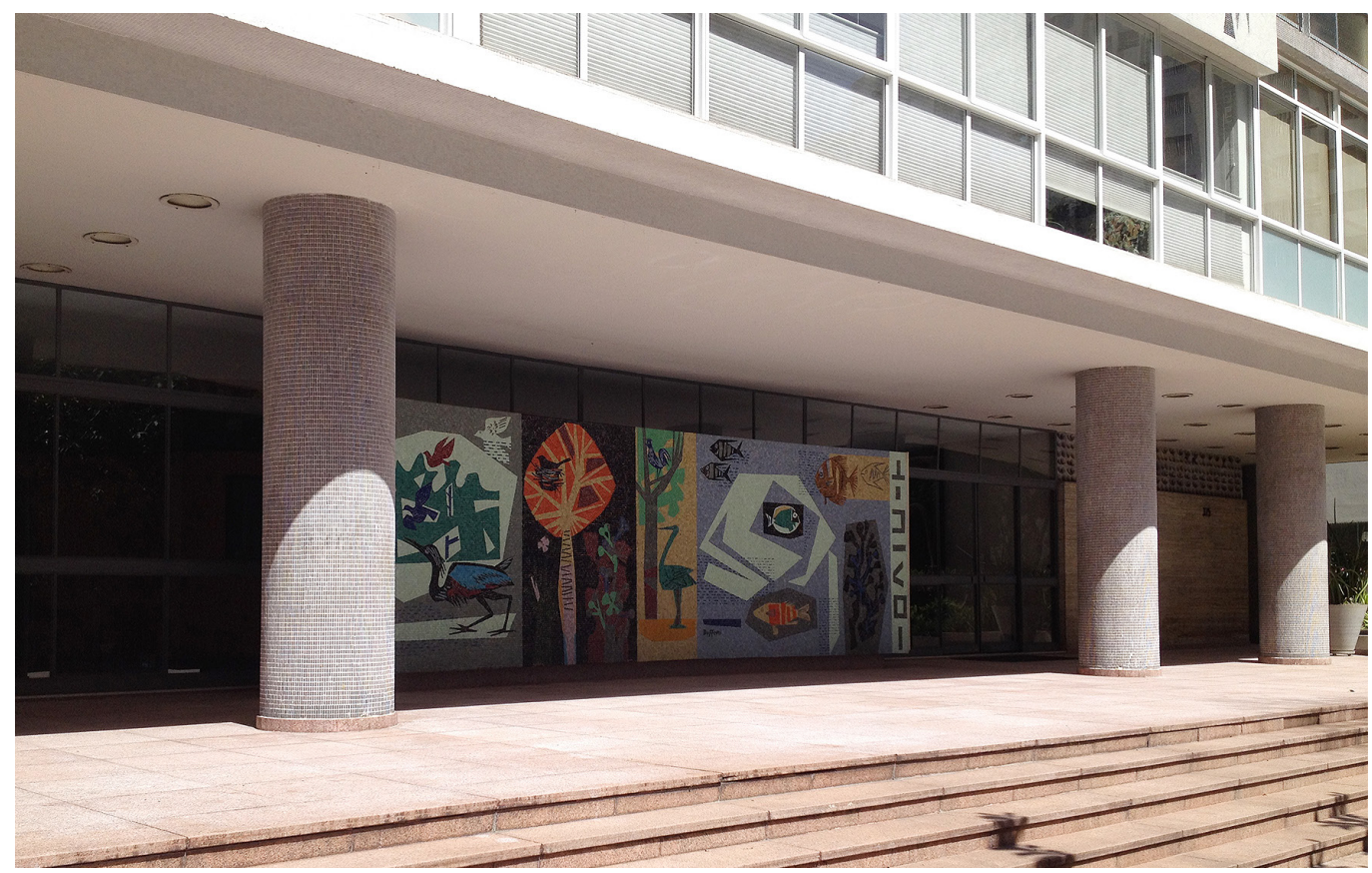

São Paulo is a cosmopolitan city, with contrasting cultures in the same space, in which the original urban layout remains visible despite the presence of modern avenidas. This makes the construction of new buildings complex, because they have to adapt to existing lots and often create subsystems with multiple functions, generating additional urban spaces and new routes. The product that follows is that of an urban image with formal discontinuities strongly accentuated, both in the size of the buildings and in the eclecticism of the styles used, with the structures that create additional subsets of urban spaces and new paths, also thanks to the use of typical elements of the language of the Modern Movement such as the elevated constructions on pilotis and the Unité d'habitation [8].

Fig. 7. O. Niemeyer, Copan Building, |96| (photo by the authors).

Fig. 8. M. Piacentini, Matarazzo Building, 1939 (photo by the authors)
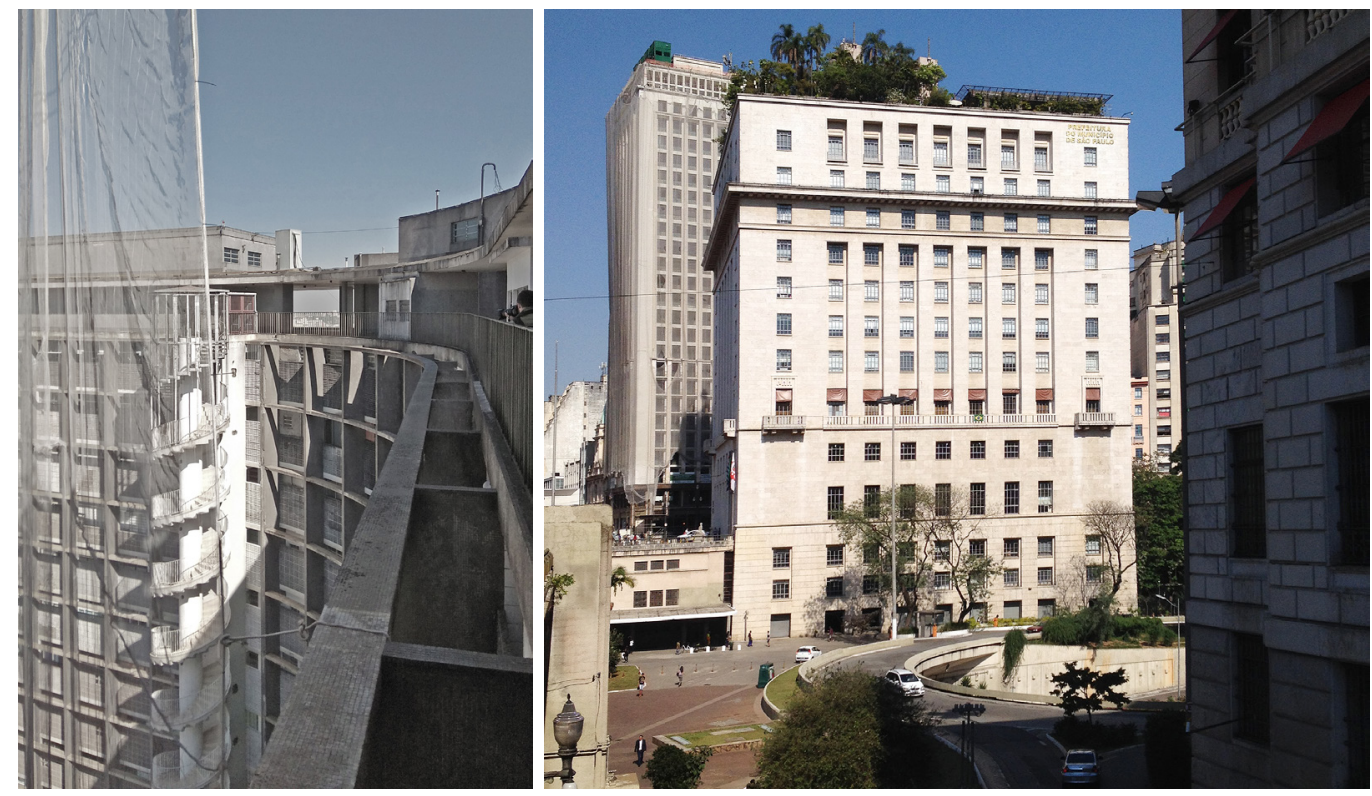

In São Paulo there are architectures with Art Deco, Neoclassical, Renaissance references, or references to the Modern Movement, the International Style and the School of Chicago, eclectically combined with traditional colonial artifacts such as mosaic decorations or with azulejos [Cottini 2020]. This search for modernity combined with the vernacular does not apply only to the design of architecture in the strict sense, but also affects the design of furniture, works of art and the surrounding landscape, just as Warchavchik had pioneeringly done during the design of his home, mentioned in the previous paragraph [Rings 20 I6]. In this regard, are worthy of note the influences exerted on the local architecture by some architects, artists and entrepreneurs who are part of the community of Italians emigrated to Brazil or who are descended from them, among which we remember Marcello Piacentini, Giancarlo Palanti, Pietro Maria Bardi, Lina Bo Bardi, Ermanno Siffredi and Maria Bardelli, Bramante Buffoni, Giuseppe Martinelli, Rino Levi. These migratory flows of intellectuals contribute to the spread in Brazil of Italian magazines such as Ricordi di architettura (I 878- 1900), Domus (1928), Casabella (1928), harbingers of practical and theoretical models that are taken as 'classic' paradigms [Cottini 2020].
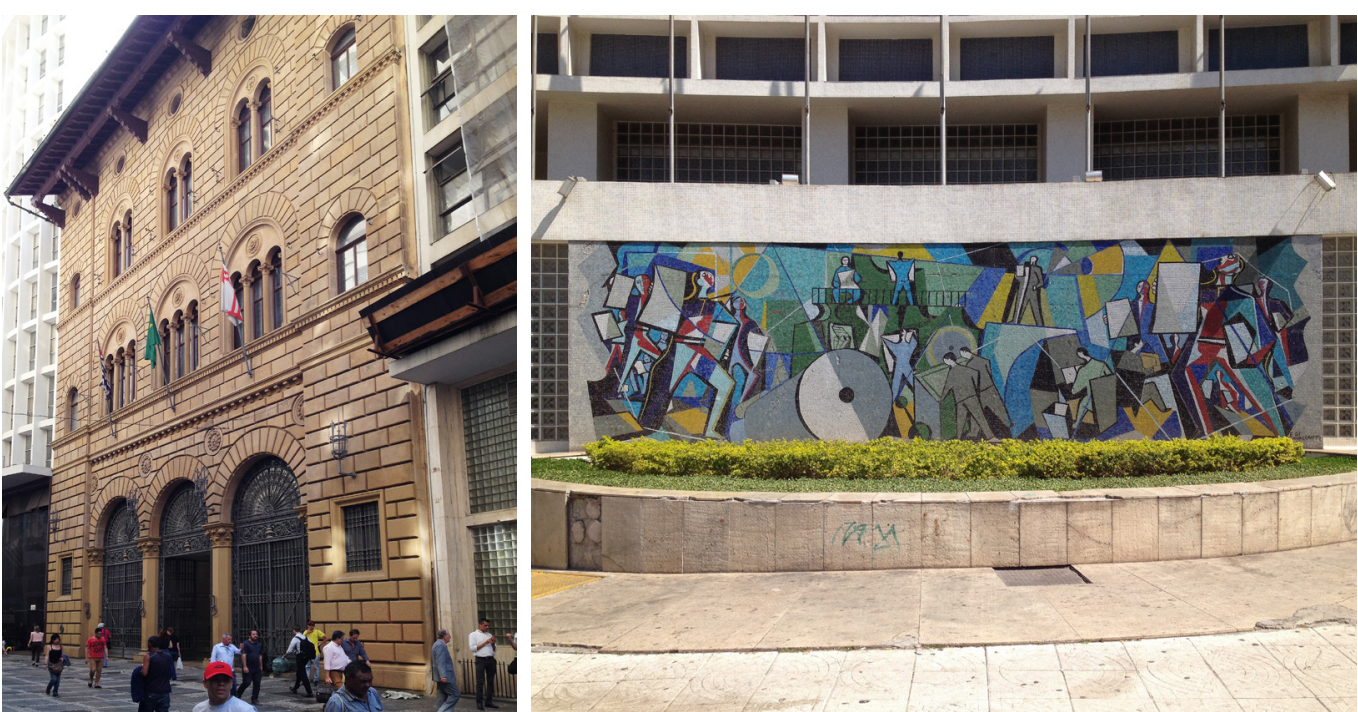


\section{The research project}

In order to safeguard the Brazilian historical heritage and traditional universal values, in 1937 the agency IPHAN (Instituto do Patrimônio Histórico e Artístico Nacional) was founded, which recognizes and protects buildings with historical relevance with the constraint of the tombamento. In the '60s, '70s and ' 80 s associations were born on the joint initiative of academics and citizens to preserve not only historical buildings, but also traditions and natural landscapes, arousing debates on the definition of Cultural Heritage [Arantes 1993].

Today there is therefore a documentation on the modern buildings of São Paulo, also iconographic, and a literature that analyzes the relationship of the latter with the city, taking into account the traditional urban layout, the contrast between the ideal city and the real city, the problem of the redevelopment of the historic center [9].

The research aims to create a network that links the modern architecture of São Paulo, in order to promote the knowledge of this heritage and make it usable even remotely. The aim is to promote knowledge of the forms in which the Modern Movement manifests itself within the city, thanks to the acquisition of documentation with integrated digital survey methodologies and photographic documentation, aimed at cataloguing and geo-referencing documented architectures.

Exploiting the potential of geo-referenced databases, it is possible to correlate a map base with different types of information that can be updated and integrated over time, derived from the study of historical sources and data acquisition in situ. This makes it possible to obtain digital maps with two parallel networks of thematic paths (in physical and virtual space) that connect the point-like manifestations of modern buildings with the dimension of the city. For this purpose, it is considered appropriate to use open source [10] geo-referencing tools of Heritage, useful both because they have no costs of use and can be customized according to individual needs, both because they aim to standardise the methodology of cataloguing the Cultural Heritage through the adoption of standards for the inventory, for the semantics of the 3D model, for the interchange of data. These tools allow institutions and professionals in the sector, after authentication, to enter data and documentation related to case studies inventoried, in relation to the contemporary and historical map bases.
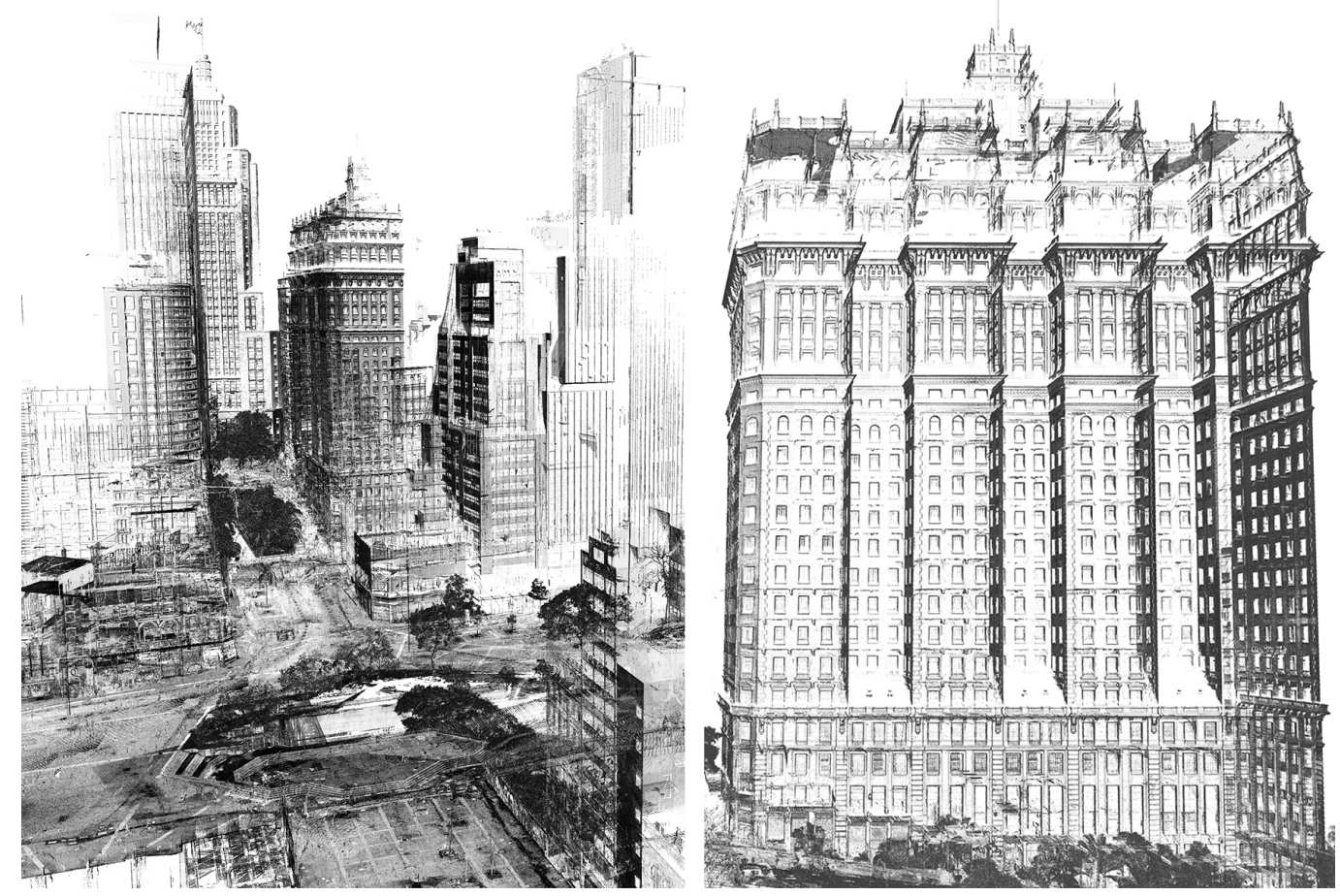
The users, whether they are experts in the sector, administrations or occasional users, can then access selected information and identify the relationships between the elements on the map, or between the elements and the territory, or even between elements and layers of information of various kinds associated with them. In this way it is possible to operate remotely at multiple scales of detail, from the global and territorial one to the one of detail of the individual components of the architectural complex.

A first example of this work is provided by the digital survey campaign carried out on the Av. São João, in the historic center of São Paulo, on the occasion of a degree thesis discussed in 2018, and of which we gave account in some publications [ $\mathrm{I}$ l] digital survey operations integrated with laser-scanner and photogrammetry was combined with an activity of scheduling the facades of urban fronts (figs. I0, I I).

Fig. I I.Top: Example of datasheet census of the facades of the buildings of Avenida São João. Below: CAD and photomapping drawing of a portion of the Avenida (graphic elaboration by A. Cottini, C. Alessi)

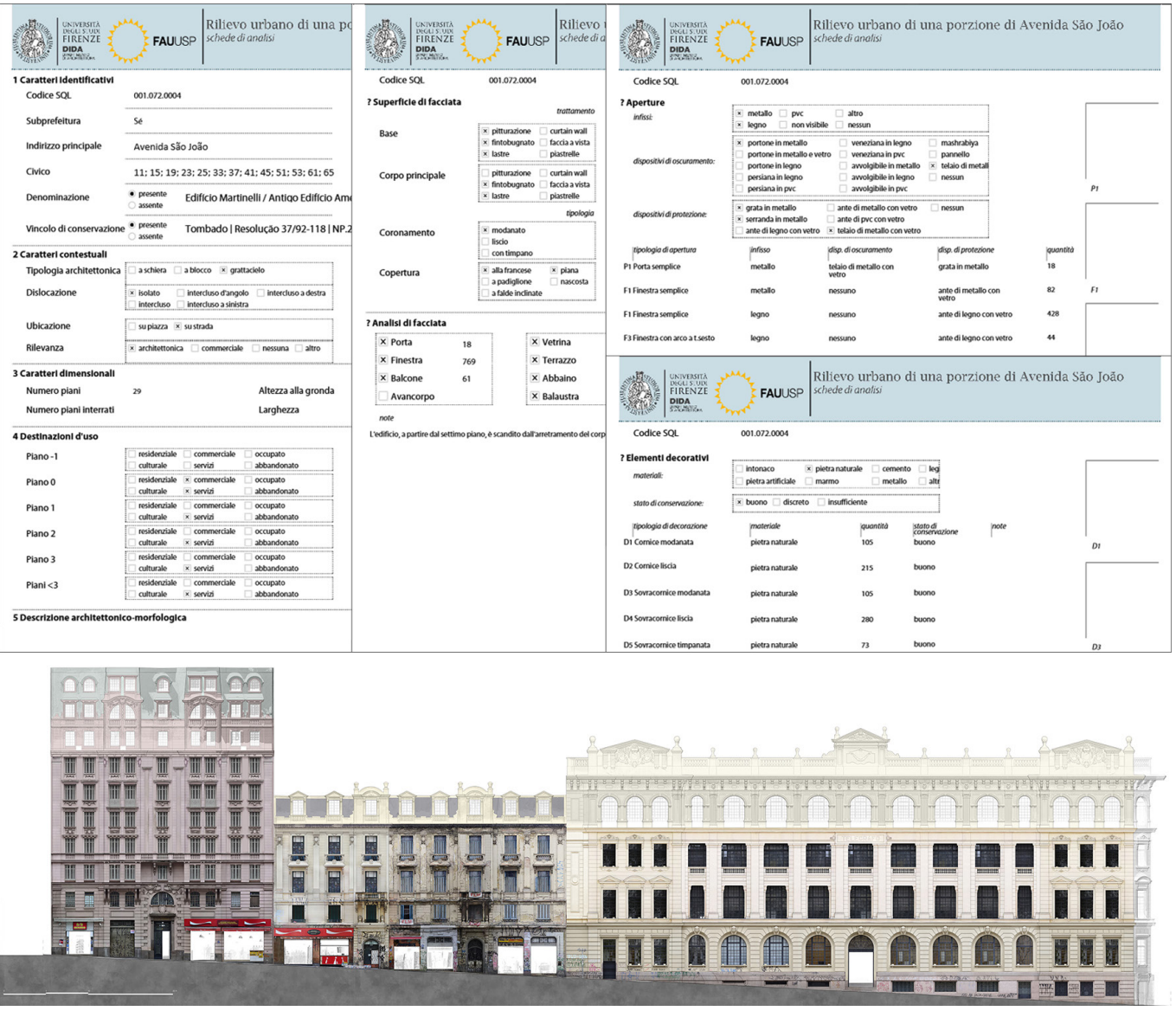

\section{Conclusions}

The 3D digital survey of the Cultural Heritage, also carried out in expeditive forms - laser scanner with photographic mapping, close-range photogrammetry, aerophotogrammetry, is useful to ensure, in addition to the conservation of the data and the form of the Heritage at the time of the investigation, remote accessibility and the dissemination of knowledge of architecture both in case it is impossible to access it physically, and for people with disabilities (virtual tour of buildings with architectural barriers, 3D printed tactile models for the blind). In this specific case, the possibility to operate with data referring to different scales of detail and geo-referenced allows to manage and visualize the whole elements of the Patrimony dislocated in the municipality of São Paulo. In addition, this makes it possible to consider the 
work in its entirety and investigate Paulist modernism as an overall project of architectural composition, interior design, integration with works of art and landscape planning. A further aspect to consider is time, as the operations of survey and documentation fix the state of the building in a precise moment and allow to recover the image in the future. In a constantly changing city such as São Paulo, it is necessary to take this factor into account and address it by updating the data after a certain period of time, for example to monitor the conservation status or changes in the intended use of the building.

\section{Notes}

[I] Prof. Lucio Gomes Machado, professor of the FAU-USP, was professor of History of Architecture and Design and curator of the 3rd and $4^{\text {th }}$ Bienais Internacionais de Arquitetura.

[2] In 1929 Le Corbusier made a trip to São Paulo and Rio de Janeiro [Muntoni 2009].

[3] In 1899 the Centre for Studies on the Resistance of Materials was founded in São Paulo, where the design and construction of reinforced concrete was studied, on the basis of a patent by the Hennebique system [Anelli R. (20I4). São Paulo: urban structure of territorial extension. In area, I | 4: <https://www.area-arch.it/sao-paulo-urban-structure-of-territorial-extension/> (accessed 2021, May 20). Between the '20s and the "40s the reinforced concrete technology spreads in academic circles and professional studios and is advertised in the magazines of the sector as a symbol of technical progress and social and economic development, to the point of reaching a real standardization [Dos Santos R.E. (2008). AA armação do concreto no Brasil. História da difusão da tecnologia do concreto armado e da construção de sua hegemonia. Belo Horizonte. História da difusão da tecnologia do concreto armado e da construção de sua hegemonia. Belo Horizonte. Doctoral thesis].

[4] Ferraz Geraldo, 1965. Warchavchik e a introdução da nova arquitetura no Brasil: 1925 to 1940. São Paulo: Museu de Arte de São Paulo, 1965

[5] Plan that structures the city growth within a system of radial streets and perimeter ring.

[6] "Three cities in a century".

[7] "The opposite of the opposite of the opposite", verse of the song Sampa (1978) by Caetano Veloso.

[8] The most famous example of this housing paradigm in São Paulo is the Copan Building (1952-66) by architect Oscar Niemeyer.

[9] See for example: Debenedetti E., Salmoni A. (1953). Italian architecture in São Paulo. Inst. Cult. Italo-Brasileiro; Lévi-Strauss C. (1996). Saudades de São Paulo. São Paulo: Instituto Moreira Salles; Goodwin. P.L. (1943). Brazil builds: architecture new and old 1652-1942. New York: The Museum of Modern Art; Segawa, H. (2010). Arquiteturas no Brasil 1900-1990. São Paulo: EDUSP. <http://centrohistoricosp.mackenzie.br/> (accessed 2021, May 20).

[I0] For example, the https://www.archesproject.org/ platform, developed by the Getty Conservation Institute and the World Monuments Fund: "Arches has been purpose-built for the international cultural heritage field, and can be used to inventory and document buildings and other structures, cultural landscapes, heritage ensembles or Districts, as well as archaeological sites. As open-source software, Arches is freely available to use and customize, without licensing or upgrade costs, and it is capable of being configured and extended to meet the needs of particular users. Arches incorporates international standards for heritage, information management, and software, leading to better practices in the creation and management of heritage data and facilitating data exchange and longevity in spite of advances in technology": <https://www.wmf.org/project/ arches-project> (accessed 2021, May 20).

[ I I] See: Cottini A. (20 I9). II disegno dei fronti urbani dell'Avenida São João nel centro storico di São Paulo in Brasile. In P. Belardi (Ed.). Riflessioni: l'arte del disegno/ il disegno dell'arte. Reflections: the art of drawing/ the drawing of art. Atti del $41^{\circ}$ Convegno UID. Perugia, 19-2I Settembre 2019, pp. 58I-588. Roma: Gangemi Editore; Bertocci S. et al. (2018). Progetti di ricerca per la documentazione del centro storico di Sao Paolo in Brasile in collaborazione con USP. In Bertocci S. Programmi multidisciplinari per l'internazionalizzazione della ricerca. Firenze: didapress; Bertocci S. et al. (2019). LabSAMPA: Rilievo nel centro storico di San Paolo per l'educazione alla tutela del patrimonio. In Bertocci S., Conte A. (Eds.). Il Simposio UID di internazionalizzazione della ricerca. Patrimoni culturali, Architettura, Paesaggio e Design tra ricerca e sperimentazione didattica. Firenze: didapress.

\section{Credits}

Introduzione, II Movimento Moderno in Brasile, II caso di Sao Paulo by di S. Bertocci

II progetto di ricerca, Conclusioni by A. Cottini

\section{References}

Anelli R. (2016). Roots of Brazilian Design: Identity and Modern Aesthetics. In SP-ARTE $365<$ https://www.sp-arte.com/en/ editorial/roots-of-brazilian-design-identity-and-modern-aesthetics-by-renato-anelli/> (accessed 202I, May 20).

Arantes A. (1993). Le pietre miliari del paesaggio urbano: Il caso del Brasile. In La Ricerca Folklorica, Brescia: Grafo Spa, n. 28, pp. $17-28$.

Cottini A. (2020). Il contributo degli architetti italiani nella San Paolo modernista. In Firenze Architettura Quaderni 2020. Oriente-Occidente rilievi, XXIV, pp. I02-107. Firenze: Firenze University Press. <https://www.wmf.org/project/arches-project> (accessed 2021 , February 22). 
Debenedetti E., Salmoni A. (1953). Architettura italiana a San Paolo. Inst. Cult. Italo-Brasileiro.

Goodwin P.L. (1943). Brazil builds: architecture new and old, I652-1942. New York:The Museum of Modern Art.

Lara F.L. (2009). Modernism Made Vernacular:The Brazilian Case. In Journal of Architectural Education, vol. 63, pp.4I-50.

Lemos C.A.C. (2016). Como nasceram as cidades brasileiras. São Paulo: Studio Nobel.

Lévi-Strauss C. (1996). Saudades de São Paulo. São Paulo: Instituto Moreira Salles.

Lima De Toledo B. (2007). São Paulo: três cidades em um sécul. São Paulo: Cosac Naify.

Muntoni A. (2009). Lineamenti di storia dell'architettura contemporanea. Bari: Editori Laterza.

Segawa H. (2010). Arquiteturas no Brasil 1900-1990. São Paulo: EDUSP: <http://centrohistoricosp.mackenzie.br/> (accessed 2021, February 22).

Vikhreva N. (2018). The roots of Brasilian Modern Architecture. In J. Cunha Pimentel, A. Trevisan, A. Cardoso (a cura di) Regionalism, Nationalism \& Modern Architecture. Proceedings. Porto: ESAP, October 25-27, 20 I 8, pp. 465-473.

\section{Authors}

Stefano Bertocci, Università degli Studi di Firenze, stefano.bertocci@unifi.it

Anastasia Cottini, Università degli Studi di Firenze, anastasia.cottini@unifi.it

To cite this chapter. Bertocci Stefano, Cottini Anastasia (202I). Itinerari di Architettura Moderna a São Paulo, Brasile/Modern architecture itineraries in São Paulo, Brazil. In Arena A., Arena M., Mediati D., Raffa P. (a cura di). Connettere. Un disegno per annodare e tessere. Linguaggi Distanze Tecnologie. Atti del $42^{\circ}$ Convegno Internazionale dei Docenti delle Discipline della Rappresentazione/Connecting. Drawing for weaving relationship. Languag-
es Distances Technologies. Proceedings of the $42^{\text {th }}$ International Conference of Representation Disciplines Teachers. Milano: FrancoAngeli, I352- I 369. 